\title{
From early literacy to information literacy
}

\author{
Fung Yee Chan \\ Li Sing Primary School
}

\begin{abstract}
Rationale
"Language is at the heart of the process of becoming literate. Through participation in these interactions, individual students construct a sense of self as readers, writers, and thinkers within the culture of each particular classroom. These constructions are salient to students' development of motivation for literacy learning." (Johnston, 1992).

Early literacy is the stepping stone to 21 st century information literacy. Here in Li Sing Primary School, I strive to enable my pupils to learn via a framework of early literacy that envelopes book handling skills, questioning, read aloud and prediction for P. 1-2 pupils. The set reading skills are extracts taken from the English Curriculum Guide published by the Education and Manpower and Bureau. ( See Appendix 1) Alongside with reading, listening, speaking is also used during everyday teaching and daily activities. Process writing and free writing has also been used to help pupils to master writing as a creative process whereby they use mind map, paragraphing and connectives to make writing a meaningful learning task.
\end{abstract}

\section{Early literacy}

A step by step approach has been used to skill children up the steps of literacy. First, phonics songs and games motivate pupils to learn. Secondly, book handling skills and read aloud are introduced hand in hand. In order to comprehend the book, questioning skills and prediction are used to elicit key information from books read. Ultimately, pupils will know how to employ the taught skills in times ahead. (See appendix 2)

Vast resources that include realia, books, online books, songs and games have been used during classroom learning so as to induce pupils to learn English.

\section{Assessment framework}

Assessment refers to the board repertoire of behaviors involved in noticing, documenting, recording, and interpreting children's behaviors and performances ... First, assessment is fundamentally interpretative, influence by values, beliefs and language, and secondly, assessment has consequences for children's literate development. (Johnston \& Rogers, 2001).

In order to check on the effectiveness of teaching and learning, I and the teacher librarian, Miss Wong Sui Fan has plan to conduct a pre-test and post-test to be undertaken during the first and second term in the year 2006-2007. (See appendix 3) 


\section{Information literacy}

During extra-curricular activities lessons, information literacy was exposed in the form of Knowledge Forum using both information technology as well as classroom discussion so as to enable P.6 pupils to ask questions, clarify information, summarizes information and last but not least to make predictions on information. In order to do so, an information technology platform was used to enable pupils to read poems by famous poets and make comments on familiar themes that are shared via a common IT platform. First, pupils are taught HOW to read a poem by using contextual clues to help them to decode the meaning of the unfamiliar words. Then, they discuss the poems using scaffolds or thinking prompts like "my interpretation of the meaning is" and state their reasons. In this way, pupils learn within an online community wherein they share their thoughts and express their comments. The pupils however, did not show that they were very enthusiastic about reading the poems even though the teachers strive to act out the poems using drama.

On second thought, I used online websites on fairytales as an entry point in order to motivate pupils to read on. Popular young adult and children's author Jane Yolen argues that in today's media influenced world, young adults lack references to the ancient myths and fairy tales that fill a basic developmental need:

- To appreciate literature, we must know the archetypes on which it is based.

- To get along with others, we must understand how our culture's values relate to theirs.

- To process our own experiences, we must compare them to those in stories.

- To build our own belief systems, we must find their roots.

(Yolen, Touch Magic, p. 5-20)

However, I was able to entice pupils to read and respond to the issues. The pupils read and were able to add into their own responses. Michael Higgins (1986) points out such elements as "flashback, conflict, and parallel structures that are common in children's stories and novels". Teachers enable pupils to understand the story using graphic organizers and grid. Moreover, teachers review the fairytale's character, plot, setting so that pupils get an overall understanding of the structural elements of the genre. The ultimate objective is to ask them to discuss online. It will be a collaborative online effort for pupils to contribute as a learning community.

Pupils are assessed quantitatively according to their participative score using an analytical tool kit. Moreover, they are also assessed qualitatively in their discussion content. It is hoped that pupils will be able to learn collaboratively as a learning community. (See appendix 4) The above experimental sessions are tried out to show the development of literacy whereupon pupils learn collectively as pupils approach 21st century information explosion. The learning process will be tracked via formative assessments done during two years of action research.

Action Research on Reading 2004/2005(Primary 1) 
1. Measures of print processing

\begin{tabular}{|l|l|}
\hline Predictor variable & No. of samples \\
\hline Basic letter-sound knowledge-phonics & 64 \\
\hline $\begin{array}{l}\text { Letter identification: naming of upper and } \\
\text { lower case letters } \\
\text { Letter recognition }\end{array}$ & 64 \\
\hline directionality & 64 \\
\hline Print concepts and book handling skills & 64 \\
\hline
\end{tabular}

2. Measures of oral language proficiency

\begin{tabular}{|l|l|}
\hline Predictor variable & No. of samples \\
\hline Speech production/speech perception & 64 \\
\hline $\begin{array}{l}\text { Expressive naming vocabulary-keywords, } \\
\text { question words }\end{array}$ & 64 \\
\hline Demonstrate voice print match-read aloud & 64 \\
\hline
\end{tabular}

3. Measures of non-verbal abilities

\begin{tabular}{|l|l|}
\hline Predictor variable & No. of samples \\
\hline Visual discrimination of first and last letter & 64 \\
\hline Visual discrimination of punctuation marks & 64 \\
\hline Space between words & 64 \\
\hline
\end{tabular}

Action Research on Reading 2005/2006( Primary 2)

\begin{tabular}{|c|c|c|c|c|c|c|c|c|c|c|c|c|}
\hline & \multicolumn{3}{|c|}{$2 \mathrm{~A}(30)$} & \multicolumn{3}{|c|}{ 2B (31) } & \multicolumn{3}{|c|}{ Overall } & \multicolumn{3}{|c|}{ Overall \% } \\
\hline & $\checkmark$ & & $x$ & $\checkmark$ & & $x$ & $\checkmark$ & & $x$ & $\checkmark$ & & $x$ \\
\hline \multicolumn{13}{|l|}{ Understand the basic convention of written English } \\
\hline 1. Recognize familiar words in new texts & 23 & 3 & 4 & 25 & 0 & 6 & 48 & 3 & 10 & $78.7 \%$ & $4.9 \%$ & $16.4 \%$ \\
\hline $\begin{array}{l}\text { 2. Use basic conventions of written English and prior } \\
\text { Knowledge of known words to read aloud short, simple } \\
\text { texts }\end{array}$ & 18 & 10 & 2 & 12 & 12 & 7 & 30 & 22 & 9 & $49.2 \%$ & $36.1 \%$ & $14.8 \%$ \\
\hline
\end{tabular}




\begin{tabular}{|c|c|c|c|c|c|c|c|c|c|c|c|c|c|}
\hline 3. & $\begin{array}{l}\text { Use Knowledge of basic letter-sound relationship to read } \\
\text { aloud simple words and short texts }\end{array}$ & 20 & 8 & 2 & 13 & 6 & 12 & 33 & 14 & 14 & $54.1 \%$ & $23.0 \%$ & $23.0 \%$ \\
\hline & & & & & & & & & & & $60.7 \%$ & $21.3 \%$ & $18.0 \%$ \\
\hline & nstruct meaning from texts & & & & & & & & & & & & \\
\hline 4. & Identify key words in a sentence & 15 & 5 & 10 & 16 & 4 & 11 & 31 & 9 & 21 & $50.8 \%$ & $14.8 \%$ & $34.4 \%$ \\
\hline 5. & $\begin{array}{l}\text { Understand the information provided on the book } \\
\text { cover(e.g. title, author and illustrator), content page and } \\
\text { page numbers }\end{array}$ & 8 & 22 & 0 & 18 & 13 & 0 & 26 & 35 & 0 & $42.6 \%$ & $57.4 \%$ & $0.0 \%$ \\
\hline 6. & $\begin{array}{l}\text { Recognize the format and language features of some } \\
\text { common text types, e.g. signs, stories }\end{array}$ & 12 & 0 & 18 & 7 & 6 & 17 & 19 & 6 & 35 & $31.7 \%$ & $10.0 \%$ & $58.3 \%$ \\
\hline 7. & $\begin{array}{l}\text { Make predictions about stories, characters, topics of } \\
\text { interest using pictorial clues and book covers }\end{array}$ & 11 & 18 & 1 & 23 & 6 & 2 & 34 & 24 & 3 & $55.7 \%$ & $39.3 \%$ & $4.9 \%$ \\
\hline & & & & & & & & & & & $45.2 \%$ & $30.4 \%$ & $24.4 \%$ \\
\hline & cate information and ideas & & & & & & & & & & & & \\
\hline & $\begin{array}{l}\text { Locate specific information in a short text in response to } \\
\text { questions. }\end{array}$ & 15 & 1 & 14 & 9 & 0 & 22 & 24 & 1 & 36 & $39.3 \%$ & $1.6 \%$ & $59.0 \%$ \\
\hline
\end{tabular}

During the year 2006-2007, teachers designed reading booklets for pupils to practice reading skills. Pupils are being exposed to a variety of different text-types, lessons on bookhandling skills, read aloud, questioning skills and prediction skills. Pupils were able to make some progress from their reading assessments during the first term. During the second term, teachers try to integrate the four skills of listening, speaking, reading and writing in an exercise book that serves as a learning diary for pupils. It is hoped that in this way, pupils can practice organizing, linking and writing what they have learnt. Moreover, it gives the teacher a clearer picture of how their pupils learn during daily lessons.

In order to widen pupils' exposure, other resources both inside and outside schools are being conducted during the year 2006-2007 as seen from below:-

Enrichment reading programs include:

- Three adult reading mums will do story telling to twelve primary two pupils.

- Reading Buddy program with St Stephen's Girls' School nine secondary school pupils will do shared reading with nine primary three pupils.

- Paired reading program within Li Sing Primary School whereby pupils in primary four conducts paired reading with primary one pupil.

- Moreover, Chinese, English, Putonghua months are held during the first and second term so as to enable pupils to have more practice in using Cantonese, English and Putonghua 
in their daily school activities. In addition, festive activities during Halloween, Christmas,

Chinese New Year and Easter are held to add in fun in the form of games, etc.

\section{From early literacy to information literacy}

To conclude, literacy will best be taught in a systematic way that include an open mind to undergo systematic action research that includes using updated online resources for formative assessment, lesson observation, detailed co-planning and long-term curriculum development. For 2007-2008, we have planned on setting up an English resource room and a guided reading program whereby pupils' diversity are being catered for.

As a curriculum officer, I had the social obligation to undertake action research that helps to build up a learning organization within my school involving all stakeholders concerned. However, nothing could have been possible without all our joint effort. To this, let's continue with our hard work and innovative planning in times ahead.

\section{Bibliography}

Anderson, P. M.(1982) .Practical applications of language learning theory in the middle school and junior high.. the Annual Meeting of the New England Association of Teachers of English.

Bosma, B,(1981) Focus on folktales for critical reading,

Higgins, M. W.(1986). Literacy through literature: improving on the basal. Wisconsin State Reading Association Journal, 30 (4), 27-36.

Moss, J.F. (1984)Focus Units in Literature: A Handbook for Elementary School Teachers, Urbana, Illinois: National Council of Teachers of English.

Nessel, D. D.(1985).Storytelling in the reading program.The Reading Teacher, 38 (4), 378-381.

Lurie, A. Don't Tell the Grown-Ups: Subversive Children's Literature, 18.

Jane, Y. Touch Magic, 5-20 


\section{Appendix}

\section{Appendix 1}

English Curriculum Guide

http://emb.gov.hk

Appendix 2

Phonics song

http://www.kiddyhouse.com/Songs/alpha/a.html

Online Resources

Stories

http://www.kizclub.com

Stories

http://www.lil-finger.com

Acknowledgement

Good and evil

http://www.surlalunefairytales.com/boardarchives/2004/jul2004/ftchildrengoodevil.html

Schedule

http://io.uwinnipeg.ca/ nodelman/fairy.htm\#schedule

Leave a reply

http://tavernadimuse.wordpress.com/2007/03/09/bluestocking-discussion-childrens-rhymes-andfairy-tales/

Teach pupils to appreciate literature

http://www.ericdigests.org/pre-928/children.htm 
Thanks to all who have contributed to make teaching and learning a satisfaction and an enjoyable experience to our children.

\section{Appendix 3}

A. Teacher Professional Development Reading Questionnaire

B. English Pre-test and post-test (reading strategies)-Miss Chan Fung Yee, Fanny

\section{A. Reading Questionnaire (Chinese Version)}

\section{李债小學}

2006-2007 年度

老師問卷調查

$\ulcorner$ 閱讀能力與策略」講座

\begin{tabular}{|c|c|c|c|c|c|c|c|c|c|c|}
\hline & $\begin{array}{l}\text { 非常 } \\
\text { 同意 }\end{array}$ & $\begin{array}{l}\text { 百份 } \\
\text { 比 }\end{array}$ & 同意 & $\begin{array}{l}\text { 百份 } \\
\text { 比 }\end{array}$ & 一般 & $\begin{array}{l}\text { 百份 } \\
\text { 比 }\end{array}$ & $\begin{array}{l}\text { 沒有 } \\
\text { 意見 }\end{array}$ & $\begin{array}{l}\text { 百份 } \\
\text { 比 }\end{array}$ & $\begin{array}{l}\text { 不同 } \\
\text { 意 }\end{array}$ & $\begin{array}{l}\text { 百份 } \\
\text { 比 }\end{array}$ \\
\hline 1. 講座內容有助本人增加對閱讀策略的認識。 & 11 & $48 \%$ & 12 & $52 \%$ & & & & & & \\
\hline 2. 講座內容配合本校閱讀策略教學推行。 & 9 & $39 \%$ & 14 & $61 \%$ & & & & & & \\
\hline 3. 講座內容能應用於本人的課堂教學-閱讀策略。 & 7 & $30 \%$ & 16 & $70 \%$ & & & & & & \\
\hline $\begin{array}{l}\text { 4. 我願意在推行閱讀策略期間, 跟同事分享教學 } \\
\text { 心得。 }\end{array}$ & 3 & $13 \%$ & 10 & $43 \%$ & 1 & $4 \%$ & 7 & $30 \%$ & 2 & $9 \%$ \\
\hline
\end{tabular}

李债小學

2006-2007 年度

老師問卷調查

$\ulcorner$ 閱讀能力與策略」講座

1. 講座內容有助本人增加對閱讀策略的認識。

非常同意 同意

2. 講座內容配合本校閱讀策略教學推行。

3. 講座內容能應用於本人的課堂教學-閱讀策略。

4. 我願意在推行閱讀策略期間，

跟同事分享教學心得。 
B. Selected pupils list

\section{閱讀策略評估對象}

中文科：

英文科：

\begin{tabular}{|c|c|c|c|c|}
\hline 班別 & 姓名 & 程度 & 前測 & 後測 \\
\hline $1 \mathrm{~A}$ & 宋卓螢 & 高 & $13 / 14$ & \\
\hline $1 \mathrm{~A}$ & 陳柏而 & 中 & $6 / 14$ & \\
\hline 1A & 陳思言 & 低 & $8 / 14$ & \\
\hline
\end{tabular}

\begin{tabular}{|c|c|c|c|c|}
\hline 班別 & 姓名 & 程度 & 前測 & 後測 \\
\hline $1 \mathrm{~A}$ & 史鳳眉 & 高 & $13 / 29$ & \\
\hline $1 \mathrm{~A}$ & 黃朗泓 & 中 & $21 / 29$ & \\
\hline $1 \mathrm{~A}$ & 陳敏怡 & 低 & $9 / 29$ & \\
\hline
\end{tabular}

\begin{tabular}{|c|c|c|c|c|}
\hline 班別 & 姓名 & 程度 & 前測 & 後測 \\
\hline 1B & 黃澤錕 & 高 & $11 / 14$ & \\
\hline 1B & 尹鈺麟 & 中 & $10 / 14$ & \\
\hline 1B & 張変欣 & 低 & $6 / 14$ & \\
\hline
\end{tabular}

\begin{tabular}{|c|c|c|c|c|}
\hline 班別 & 姓名 & 程度 & 前測 & 後測 \\
\hline 1B & 李沛澄 & 高 & $11 / 29$ & \\
\hline 1B & 李子朗 & 中 & $7 / 29$ & \\
\hline 1B & 鄭彩浩 & 低 & $6 / 29$ & \\
\hline
\end{tabular}

\begin{tabular}{|c|c|c|c|c|}
\hline 班別 & 姓名 & 程度 & 前測 & 後測 \\
\hline $2 \mathrm{~A}$ & 麥麗怡 & 高 & $11 / 15$ & \\
\hline $2 \mathrm{~A}$ & 黃皓鈺 & 中 & $\mathrm{ABS}$ & \\
\hline $2 \mathrm{~A}$ & 趙惠沁 & 低 & $9 / 15$ & \\
\hline
\end{tabular}

\begin{tabular}{|c|c|c|c|c|}
\hline 班別 & 姓名 & 程度 & 前測 & 後測 \\
\hline $2 \mathrm{~A}$ & 潘惜譽 & 高 & $27 / 30$ & \\
\hline $2 \mathrm{~A}$ & 李柏軒 & 中 & $16 / 30$ & \\
\hline $2 \mathrm{~A}$ & 殷學賢 & 低 & $11 / 30$ & \\
\hline
\end{tabular}

\begin{tabular}{|c|c|c|c|c|}
\hline 班別 & 姓名 & 程度 & 前測 & 後測 \\
\hline 2B & 陳伯聰 & 高 & $11 / 15$ & \\
\hline 2B & 鍾浩軒 & 中 & $11 / 15$ & \\
\hline 2B & 寉衍華 & 低 & $12 / 15$ & \\
\hline
\end{tabular}

\begin{tabular}{|c|c|c|c|c|}
\hline 班別 & 姓名 & 程度 & 前測 & 後測 \\
\hline 2B & 陳伯聰 & 高 & $25 / 30$ & \\
\hline $2 \mathrm{~B}$ & 蕭子峰 & 中 & $17 / 30$ & \\
\hline 2B & 陳志錩 & 低 & $6 / 30$ & \\
\hline
\end{tabular}

B. Pretest and Post-test on reading strategies (English)

English Reading Skills

Li Sing Primary School 2006-2007

School-based Action Research on Reading Strategies

Pre-test for P.1/2 English

a) Book Handling skills (Front Cover)

- Title

- Author

- Illustrator

b) Prediction Skills

1. Pictorial Clues 
2. Contextual Clues

3. Key Words

c) Questioning Skills
1. Who
2. When
3. What
4. Where
5. Why
6. How

d) Read Aloud
1. Pronunciation
2. Intonation
3. Fluency

Appendix 4

Knowledge Forum

http://kf5.cite.hku.hk

http://lcp.cite.hku.hk

http://www.lsps.edu.hk 